\title{
Destin, Design, Dasein: Lacan, Derrida and "The Purloined Letter" . Claude Richard*
}

FOR THE SECOND TIME in the rich history of FrancoAmerican misunderstanding, Edgar Allan Poe is becoming, in France, one of the most important American writers. Since cultural anger and ironical puzzlement are likely to be as strident in American Academe as they have been over the last century at Baudelaire's and Mallarmé's supposed blindness to Poe's vulgarity, I wish to emphasize at once that the new recognition of Poe situates itself on a radically non-aesthetic plane. If Poe has become so meaningful to contemporary French criticism, it is because his texts respond admirably to the new questions addressed to literature from the whole gamut of French contemporary thought. What is perhaps difficult to realize, here in America, is that in the list of contemporary writers and critics who write about or around Poe, we find practically all the major names: Poulet, Bachelard, Ricardou, Todorov, Genette, Barthes, Lacan and Derrida.

One of Poe's texts-"The Purloined Letter"- has become the arena where one of the fundamental debates of contemporary criticism is being held. Do not however, be worried: I am not going to give a talk about Poe. I know better than that: I have learnt that when one wants to be taken seriously in the United States, one does not give a talk about Poe. It seems that if one wants to be taken seriously, one gives a talk about contemporary French philosophy: I am not sure however that French philosophy will sound very serious to you if I elaborate on Derrida's latest pun, "connect I cut," and if I assert that dasein is Lacan's favorite dessert.

The basis of modernity is the seriousness of playfulness; the game is played with words and, even if, with some American critics, we blind ourselves to the brilliantly exemplified experimentations with arbitrary signifiers where pokerfaced Poe illustrated the fecundity of systematic formalization and dislocation of meaning, we shall still meet on our path many post modern Imps of the Perverse playing their game of hide and sex.

The game we are going to play today began in 1844 when Poe, having

\footnotetext{
*A lecture given at the University of Iowa on December 6, 1980 and printed with Professor Richard's permission.
} 
invented and exhausted the so-called genre of the detective story in "The Murders in the Rue Morgue," decided to write a meta-detective story about the theft of that letter which enables one to write detective stories, made it into another allegory of the poet as priest, and forever forgot about detective stories, passing on to what he regarded as his "legitimate thesis," the Universe and to the writing of one of the unacknowledged masterpieces of modernity, Eureka.

Thus the riddle of the day is: "what has happened to the purloined letter" and the game of the day is "uncover the letter to recover the letter"-a game played with admirable devotion, over the last few years, in Paris and in New Haven.

The game may appear frivolous to you-as will any destabilization of an old comfortable category by word play_but, maybe, the formidable names of the players will force us into some kind of respect and help us realize that the issues at stake are crucial to nothing less than the meaning of the Lacanian "subject," the sense of Derridean deconstruction and therefore to nothing less than the relevance of the problem of meaning in communication.

Between 1845 and 1956, not much happened in the realm of the purloined letter, except that Marie Bonaparte read it-to nobody's surprise - as the "struggle between father and son ... to seize possession ... of the penis ... of the mother," thus making the cheeks of the fireplace between which the letter hangs, the most famous pair of jambs, or gambs, in the history of literary criticism.

In 1956, Lacan published "The Seminar on 'The Purloined Letter' ": that text however, did not actually make its full impact felt until it was placed by Lacan himself at the head of a book, Ecrits which, over the last decade, has become a challenge and a nightmare for a whole generation of intellectuals. When Ecrits was reprinted in the popular collection, Points, not only did Lacan leave "The Seminar" at the head of the book as a reminder that it was the cornerstone of his system; he also added a new introduction in which he emphasized more clearly than before the fact that an understanding of what was really happening in Poe's tale was crucial to an understanding of Lacan's central concept-the idea that "the only master is the signifier."

We are only emerging from an age that has asserted with unusual energy that we are language, nothing but language. This is the age of Saussure and Levi-Strauss before being the age of Deleuze; this is an age to subscribe to Heidegger's statement that "words and language are not 
wrappings in which things are packed for the commerce of those who speak and write." Lacan is the son of Saussure and Heidegger. He would certainly not deny that "it is in words and language that things first come into being and are." He would certainly go further and would probably agree that it is in the letter that men come into being and are.

What "The Seminar on 'The Purloined Letter' " contributed is both easy and impossible to state, but it is indisputably the most unequivocal assertion that language is the primal cause. Before attempting to summarize this contribution, it might be useful to dispose of the inevitable remark - which came from Yale, with the deadly industrial precision brought by American critics to the minimization of Poe-that Poe's text is only a pretext for Lacan. This is precisely where we should begin: as Lacan makes it clear, Poe's text is the pre-text. As proto-text, "The Purloined Letter" has verbalized, once and forever, some of the potentialities of the discourse of psychoanalysis. To be more specific, Poe in "The Purloined Letter" has dreamt and worded not only the relationship between the repetition automatism and the insistence of the signifying chain but also the process through which "the displacement of the subjects is determined by the place which a signifier-the purloined letter-comes to occupy" in the successive trios which constitute the intersubjective modulus. In other words, Poe's tale appears as the perfect metaphor of the discourse of psychoanalysis insofar as that discourse is a discovery of the split. Or again - and to remind you briefly of the diegesis of the tale-what Lacan points out is that the basic structure of Poe's tale is founded on the repetition of a situation involving each time three agents, that is to say on the compulsive repetition of triads: the first scene, called the primal scene, involves the Queen, the King and the Minister D_-, who steals a letter addressed to the Queen. The second scene involves the Minister D-, Dupin and the police: during a visit to D-'s house, Dupin manages to steal the letter from D- and to leave, as D-did previously, a facsimile - a simulacrum of a letter-in the card-rack where the original letter had been concealed by its very gaudy exhibition, that is to say by the very fact that it was, like all signifiers, "a little too self-evident."

What essentially interests Lacan is, first that this signifier-without-asignified (the content of the letter is never disclosed) is a letter, that is to say a material signifier, secondly that the fact that this unread message is retransmitted "assures us of what may, by no means, be taken for granted: that it belongs to the dimension of language." 
The invisibility of the letter, which has remained undiscovered in spite of the meticulous search of the police, demonstrates its nullibility in spite of its unquestionable materiality as signifier. The concealedunconcealed letter is thus shown to be truly odd (that is to say to belong to the order of the one as opposed to the imaginary order of the two) and thus to "not admit of partition." The indivisibility of the letter (you cannot talk of "some letter") - whether it be typographical character or epistle-makes it the perfect image of "the signifier-a unit in its very uniqueness, being by nature symbol only of an absence."

Lacan may now come to what he calls "the true subject of the tale"- the true subject of any tale: the purloining of a letter, the fact that its trajectory is prolonged and that it thus becomes "a letter in sufferance," in other words, the delayed (or diverted) itinerary of a signifier on the signifying chain will determine how "the subjects, grasped in their intersubjectivity ..., will model their very being on the moment of the signifying chain which traverses them."

This is therefore man's destin, this is man's destiny, what Freud discovered with a perpetually increasing sense of shock, the awareness that "the displacement of the signifier determines the subjects in their acts."

Thus Poe's tragic imagination-an imagination of absence and motion as revealed by the structure of the cosmos in Eureka-allowed him to fictionalize the "gripping truth" according to which he who holds the letter is bound to go through a phase determined by the signifier and, more particularly, through a phase of femininity: the Queen, then D-, then Dupin will exude the oddest odor di femina as long as they are "in possession of the letter"; that is to say, as long as they are possessed by the letter they possess.

"What Poe's tale shows," writes Lacan in the introduction to the Points edition, "is that the effect of the signifier bears primarily on its post-theft possessor and that along its travels what it conveys is the very femininity which it is to have taken into its shadow."

Thus Dupin's final involvement in the "intersubjective triad" leads him to feel "a rage of manifestly feminine nature" and "to turn toward the medusoid face of the signifier"; that is to say, to be petrified and blinded when he confronts the final remaining trace written on the simulacrum of the letter, the quotation from Crébillon he had scribbled in the facsimile he has left in the rack in the place of the original letter. It reads: "Un dessein si funeste, s'il n'est digne d'Atrée est digne de Thyeste" "“so infamous a design, if not worthy of Atreus, is worthy of Thyestes"). 
It is however well known by now that Lacan, at the end of his article, misquotes both Crébillon and Poe. Twice he writes "un destin si funeste" ("so infamous-or baleful-a destiny"). In the same way as Poe is-as he liked to remind his readers-a poet to a $\mathrm{T}$, destin is dessein to a $\mathrm{T}$. What remains therefore is the question of the purloined letter. For Lacan's version of the quotation, in spite of the over-ingenious explanations of French and American disciples, simply means what it says: it says that the letter dictates man's destiny whereas the emphasis in Crébillon's line was on man's exercise on his free will, on his design; that is to say, on the human responsibility in the curse on the House of Atreus.

Lacan does comment on destin-destiny with unusual clarity: "so runs the signifier's answer .... 'You think you act when I stir you at the mercy of the bonds through which I knot your desires.' "What the misquotation allows him to do is to show the multiplication of the objects of desire in the case of the tragic Don Juan and to bring in the idea that "the letters on the wall that dictate his destiny [destin]" will "be his feast until the return of the stone guest." Destiny is destin but feast is festin. Festin is, naturally, destin to a D and no feast is complete without dessert: "the signifier's answer to whoever interrogates it, is [writes Lacan] 'Eat your Dasein.' " Destiny contradicts Dasein because Dasein denies the concept of Lacanian subject insofar as the subject is the absent product of its linguistic cause, the letter, which will always arrive at its destination because destination is the destiny of the letter.

The last few sentences you have no doubt recognized as the gist of Derrida's critique of Lacan's "Seminar" first published in 1975, immediately translated into English under the title "The Purveyor of Truth" and reprinted with many additional comments in Derrida's most recent book, La Carte postale.

Derrida's critique, which will eventually raise the problem of the structure of the act of communication, reaches in two directions: first, it attempts to demontrate that Lacan eliminates "the scene of writing" because he is concerned with truth- "not any truth but the truth itself, the truth of the truth" - that Lacan's truth is castration and that, consequently, as Purveyor of Truth or, more precisely, as the postman who delivers the truth, Lacan is nothing but a belated metaphysician. His metaphysics are the eternal metaphysics of presence, that is to say, in the case of castration, the presence of an absence. His second and consequential argument concerns what seems to be at stake not only in contemporary linguistics but in the whole field of modernity, from John 
Barth to Thomas Pynchon; I mean the itinerary of the letter as signifier in the act of communication. To Derrida a "letter does not always arrive at its destination and since this belongs to its structure, it can be said that it never really arrives there, and that when it arrives, its possibly-notarriving torments it with an internal divergence."

The neutralization of the scene of writing is brilliantly demonstrated when Derrida shows how Lacan can isolate two repetitive triangular scenes only because he works exclusively on the contents of the tale, the nakedness of the Freudian stoff, at the expense of the act of narration and more precisely of the presence of the narrator. The exclusion of the narrator of the story-that old reflex of scholarly hermeneutics which ultimately achieves the most paradoxicallevaluation of thenarrator as the agency who is alien to his narration-allows Lacan to gloss over the linguistic act of telling and to present the "displacement of the signifier as a signified, as the recounted object" or subject matter in Poe's story, that is to say as the truth of the story unveiled by the discourse of Dupin-the-analyst in a Heideggerian act of aletheia. Thus, the truth of the story would, paradoxically, be independent of the narration, which is disposed of under the name of secondary elaboration.

In the case of "The Purloined Letter" it implies that if the very important role played by the "narrating narrator" (as opposed to the "narrated narrator") is taken into account, Lacan's "narrated triangular scenes" become quadrangles, in other words series of duplicated doubles or couples, brotherly or otherwise, whose dissemination saves them from the fatality of endless displacement in the enclosure of the triangular modulus.

Lacan's tendency to triangulate "The Purloined Letter" is dictated by a psychoanalytical-transcendental topology - which implies that, even though the signifier "has no self-identical place," it will always follow a single proper trajectory and that, in order to tread circularly back upon its own topological tracks, the letter must end up where it should be, at the place of castration, when it forces its holder to occupy the place of woman, a place where what is veiled-unveiled is a hole, a non-being. The place of the signifier, in Lacan's thought, is finally revealed to be where Marie Bonaparte had discovered it, on the immense body of the woman sprawled across the room of D-, between the cheeks or the jambs of the fireplace from whose mantelpiece it hangs. For Derrida, Lacan's ultimate truth is that "the link between femininity and truth is its ultimate signified." Thus the Truth of the Truth would be castra- 
tion. As castration is what "contracts to bring the phallus, the signifier, the letter or the fetish back to their oikos, their familiar dwelling," the phallus may travel in peace along its transcendental Moebius strip. The Law is preserved.

What threatens the Law is dissemination and in particular dissemination of letters. As long as the post office is the law (the royal mail, a state monopoly), letters will reach their destination. Even letters in sufferance, Scarlet Letters, so to speak. There exists however a Dead Letter Office and, once in a while, a scrivener prefers not to transmit the letter. So that the letters which end up in the graveyard of the post office or on the desk of Bartleby never reach their destination. This is the genuine post office reform, the taking of the letter from the mailman whose eternal function has been to deliver the letter to the female. That is the basis of Derrida's deconstruction of the all-powerful scheme of the Lacanian act of communication: if the sender succeeds in sending a letter to a receiver, even if the sender is defined as "he who receives from the receiver his own message in reverse form," what is postulated is that some literal part of the message always arrives at its destination, that is to say that the letter is the destiny of both the sender and the receiver. But the idea of destination itself, an idea Derrida equates in $\mathrm{La}$ Carte postale with the idea of death, rests entirely on the acceptance of the materiality of the letter deduced from its indivisibility, which, for Derrida, "is not found anywhere" and which can thus be properly called an idealization. Communication is seen by Lacan as a contract between two presents and even if communication does not communicate anything, it communicates itself: "the discourse represents the existence of communication ...; even if it denies the obvious, it affirms that the Word constitutes the Truth." If, truly, the existence of communication is the truth of communication-what Derrida very Poesquely calls "the power of the [spoken] word ... testifying to the truth"- then the letter does arrive at its destination. But "l'écriture avant la lettre"-."writing before the letter" which has already deconstructed the totalitarian phallogocentrism of philosophy, demonstrates that "The Purloined Letter" is but a letter in a chain of letters and that no letter ever arrives at its destination. The proof is that the cannibalistic dessein (design) of the brother of Atreus has become the destin of the subject and that "design" has been turned into the dasein of the Parisian sleuth: in fact, as Derrida demonstrates, Lacan "carries dasein back to the subject." The letter is therefore revealed as divisible and thus loses any assurance of destination. 
It can, in particular, be shared, notably by two brothers. Derrida does allude briefly to the dedoubling of the characters in "The Purloined Letter" ("brothers or confrères") to show how the so-called "unity" of the tale is carried into an endless drifting-off course and a labyrinth of doubles without originals. When, in the signature of his tale, Poe-Dupin alludes to the relationship between Atreus and Thyestes, he is obviously alluding to another archetypal couple, the couple of brothers, and to the curse of sameness in difference.

The organizing motif of the tale is, as a matter of fact, the brotherly couple: Atreus and Thyestes, the narrator and Dupin, D- and his brother-poet and mathematician-the King and the Prefect, and finally, Dupin and D-.

"The Purloined Letter" has bravely born the brunt of the battle fought on its ring, but no one is going to make me believe that the last word has been taken from the text and that Poe is not smirking with glee somewhere in the Hell of Humanists recently converted into Paradise for Structuralists. That Dupin and D-tend to identify throughout the tale will be obvious to anyone who is not concerned with using the tale for the construction or deconstruction of a system, even if that reader did not know that Dupin's real life model, André Marie Jean Jacques Dupin had a brother, Charles Pierre Dupin, and even if that reader had forgotten that Dupin is described as "a bi-part soul" who engages in the hunt for the Great Tawny Ape of the Rue Morgue in order to vindicate Lebon, his good side, mistaken by the blind police of Paris for his ontological brother, the hideous monstrum horrendum of the repressed self. It would have been enough to realize that from the vast alphabetic scale offering a paradigmatic choice of 26 letters, Poe, the master of conundrums, elected to name the Minister D, thus making him share with Dupin the signifier D, making them, therefore, different to a $\mathrm{D}$, that is to say similar in their difference. The rest of the paternal name is but a syntagmatic sequel deprived of its liberty to differ by the determinism of the inaugural $D$.

It should be pretty obvious that the purloining of the letter stands, in the tale, as a mirror metaphor of the theft of a D. Dupin and D-, those Siamese twins in the fashion of Atreus and Thyestes or in the fashion of Chang and Eng, are linked by the flesh-the flesh of the children of Thyestes devoured in a cannibalistic festin (feast) or the flesh of the letter that welds them together for the worst of destinies (destin). To be welded to one's brother by a leash of flesh-symbolical 
or literal-to be, as John Barth would put it, two in one, to be at the same time "I" and "the other," to be both oneself and one's sign, to be neither one nor quite two, condemns Dupin-the-writer to "school himself in detachment" and "to lust for disjunction."

When he learns about the theft of the letter, Dupin understands that, symbolically, the Minister D- has stolen his D, depriving him of his integrity, dividing his signifier-his paternal name-which constitutes the essence or rather the letter of his identity. This may be regarded as structuralist's delirium. Let us, nevertheless, return to the letter of the text of Poe. That the whole story is concerned with the differentiation of one and two is obvious from the beginning. It is a story at the same time "simple and odd" (double $\mathrm{d}$ ), a business which is, to quote the Prefect, "simple in-deed" and it deals, among other things, with the idea developed by Dupin that "two motives, each of a given value, have not necessarily a value, when united, equal to the sum of their values apart."

With twin, or nearly twin, brothers, that is to say with the subject, whatever is simple is odd, because to be one is to be two. The subject is two-in-one like a Moebius strip, yearning for the split, longing, as Dupin himself puts it, "to be even with him," that is to say to transform the one twoness into two onenesses by recovering his D.

The Minister indeed, has more than just stolen a D from Dupin: he has hoarded D's into the cellar of his self: he owns such an excess of letters that he can afford to leave his own letter upon the table, his hotel is called the $\mathrm{D}$ - hotel, all his papers show the $\mathrm{D}$ - sign, he has written on Differential Calculus and his large black seal bears the D-cipher. More convincingly still, he appears to Dupin as the illegal holder of a stock of illegitimate D's as he, Dupin, "reflects [like a mirror-a very envious mirror-] upon the daring, dashing and discriminating ingenuity of D-." I am not prepared to believe that this is not deliberate.

Dupin's design is obviously to liberate his D or to reclaim his letter because, on account of "its susceptibility of being destroyed," he is, when deprived of his D, "driven to despair." Thus, in order to "redirect" the letter, Dupin will resort to the simulacrum of writing: he will replace the letter by a facsimile and, in order to recover his property, he will "imitate the D-cipher." The last doubt we might have, will, I hope, be dispelled, when we take into consideration the signifier he uses (or is used by) to express his victory: "I bade the Minister good morning and took my de-parture."

The Minister, who, as you have noticed, is in his turn, deprived of 
his D, is consequently a "desperate man" whose "downfall" is properly called a political "de-struction." Now the destruction of the Minister $\mathrm{D}$ has been, we remember, achieved by Dupin through a process very properly described, by both Dupin and the narrator, as "a process of identification." The successful recovery of the D seems therefore to aim at the reconstruction of Dupin's identity which has been destroyed by the Minister D-.

By ministering to his D, Dupin reconstructs his broken identity, achieves the reunification of $I$ and $D$, thereby demonstrating that oneness can be and is. The age believed in the conjunction of I and D; Poe believed in oneness.

If identity is the union of I and D, to steal the D is to reduce the I to the bare ego which is an illusion of identity begot by the ideology of presence.

Dupin however will not egoistically and gluttonously feed on his newly reconstructed I.D. He will share the feast with the narrator in the palace of imagination and together they will write a story, entitled "The Purloined Letter," which shows that two brothers can share the House of Atreus as long as no D is appropriated by an I, no letter possessed by a sender, no language owned by the writer.

The function of the letter is to travel back and forth incessantly from one subject to another, to underline that there is no sender and no receiver, that we have always known, with Derrida, that Plato had been dictating to Socrates the message Socrates had received from Plato who had got it from Socrates.

In order to write, you must be two, like Deleuze and Guattari, and as each of the two is many persons, what it means is that it takes a lot of people to write a letter. That is the grand opening of Deleuze and Guattari's Rhizome and this is where we might conclude, if to conclude were not to attempt to arrest or put an end to a D. Thus, as I do not know how to conclude, I shall, with your permission, simply take my leave without delay.

\section{"The Purloined Letter" dossier}

1. Bonaparte, Marie. Edgar Poe: Étude psychanalytique. Paris: Denoël et Steele, 1933, 2 vols. (Paris: P.U.F., 3 vols.) translated by J. Rodker, London: Imago Publishing Company, 1949. 
2. Lacan, Jacques. "Ouverture de ce recueil" and "Le Séminaire sur La Lettre volee" in Ecrits, Paris: Le Seuil, pp. 9-10 and 11-61. (Reprinted 1971 in Ecrits, Paris: Le Seuil, Collection "Points," pp. 19-75 with a new introduction (pp. 7-12) dated December 14, 1969.)

"Seminar on 'The Purloined Letter,' " translated by Jeffrey

Mehlman, Yale French Studies, 48 (1973), $38-72$ (issue entitled French Freud) (An abridged version. Reprinted in, Aesthetics To-Day, revised edition, eds. Morris Philipson and Paul J. Gudel, N.Y.: N.A.L., 1980, pp. 382-412).

3. Derrida, Jacques. "Le Facteur de la vérité," Poétique, 21 (1975), pp. 96-148, reprinted in La Carte postale. Paris: Aubier-Flammarion, 1980 (La Carte postale includes many allusions to "The Purloined Letter," to Lacan's "Seminar" and to B. Johnson's and F. Jameson's articles. See infra).

"The Purveyor of Truth," translated by Willis Domingo, James Hulbert, Moshe Ron and M.-L.R., Yale French Studies, 52 (1975), 31-113 (the issue is entitled Graphesis).

4. Roustang, François. Un Destin si funeste (sic). Paris: Editions de Minuit, 1976.

5. Johnson, Barbara. "The Frame of Reference: Poe, Lacan, Derrida," Yale French Studies 55/56 (1977), 457-505 (the issue is entitled Literature and Psychoanalysis).

6. Jameson, Frederic. "Imaginary and Symbolic in Lacan: Marxism, Psychoanalytical Criticism and the Problem of the Subject," Ibid., pp. 338-395.

7. Holland, Norman N. "Recovering 'The Purloined Letter,' Reading as a Personal Transaction," in Susan R. Suleiman and Inge Crosman eds., The Reader in the Text, Essays on Audience and Interpretation, Princeton University Press, 1980, pp. 350-370.

8. Mehlman, Jeffrey. "Poe Pourri: Lacan's Purloined Letter," in Aesthetics To-Day, pp. 413-433.

9. A recent number of Tel Quel, LXXXVII (Spring 1981) contains incidental remarks on "The Purloined Letter" by Ph. Sollers, J.L. Giribone and an interesting article by Françoise P. Lévy, "La Lettre ..." (pp. 64-73) which explores the implications of Lacan's neglect of the content of the letter. 